\title{
Auditor expertise: Evidence from the public sector
}

\author{
Mark Schelker* \\ Department of Economics and Swiss Institute for International Economics and Applied Economic Research (SIAW), University of St. Gallen, Bodanstrasse 8, 9000 St. Gallen, \\ Switzerland \\ CESifo, Germany \\ Center for Research in Economics, Management and the Arts (CREMA), Switzerland
}

\section{A R T I C L E I N F O}

\section{Article history:}

Received 12 November 2009

Received in revised form

7 March 2012

Accepted 20 April 2012

Available online 27 April 2012

\section{JEL classification:}

D70

H10

\section{Keywords:}

Public auditor

Auditor expertise

Auditor competence

\begin{abstract}
A B S T R A C T
This paper is the first attempt to study the relationship between public auditor expertise and fiscal performance. I find that states requiring the auditor to hold a professional degree feature significantly higher credit ratings and lower expenditures and debt. (39 words)
\end{abstract}

(c) 2012 Elsevier B.V. All rights reserved.

\section{Auditor expertise}

In the political process the quality, quantity and timing of information is, to a great extent, determined by transparency and supervision requirements (e.g., Alt and Lassen, 2006). Auditors are a fundamental supervising institutions in the public as well as the corporate sector to ensure that reported information is accurate. Without accurate information citizens as well as investors would find it difficult to make adequate decisions. Since agents face strong incentives to misreport, independent audits are crucial. ${ }^{1}$

The few economic contributions on public auditing so far emphasize the important functions of auditors in controlling the government and the bureaucracy by providing information to policymakers and citizens, and in exposing waste and corruption (e.g., Frey, 1994, Schelker, 2008). In field experiments Olken (2007) and Ferraz and Finan (2008) provide evidence that financial audits reduce wasteful spending and improve the quality of information. In addition to financial audits some auditing institutions also

\footnotetext{
* Correspondence to: Department of Economics and Swiss Institute for International Economics and Applied Economic Research (SIAW), University of St. Gallen, Bodanstrasse 8, 9000 St. Gallen, Switzerland. Tel.: +41712242578.

E-mail address: mark.schelker@unisg.ch.

1 Recent experiences (e.g., EURO Area) as well as academic research shows that there is ample evidence for 'creative accounting' in the public sector (e.g., von Hagen and Wolff, 2006).
}

conduct performance audits, which tend to improve policy outcomes (Schelker, 2008). Schelker and Eichenberger (2010) analyze the influence of extending the audit mandate to include ex ante audits of the budget draft and individual policy proposals and find significantly lower taxes and expenditures. Research on auditor independence shows that limiting auditor tenure by binding term limits improves credit ratings, while there seems to be no clear effect of auditor appointment and removal procedures (Schelker, 2008, 2012).

In the corporate auditing literature, one of the main drivers of audit quality is auditor expertise. So far however, there is no evidence on the influence of auditor expertise in the public sector. Due to electoral pressure or career concerns, public decision makers face incentives to misreport. Audit expertise is likely to influence these incentives. If more competent auditors detect inaccurate reporting and fiscal data management with a higher probability, the informational content of fiscal information improves, which enables citizens and investors to make more appropriate electoral and investment decisions.

The public auditing institution is typically a large bureaucracy and it would be very difficult to assess the overall expertise within such a complex structure. This study focuses on the influence of professional expertise of the chief auditor. He enjoys a high degree of autonomy within the legal and regulatory framework and defines the audit mandate, strategy and policy, which includes the focus of the conducted audits, its timing, priorities and thoroughness. 
Table 1

The influence of auditor expertise on state GOB rating.

\begin{tabular}{|c|c|c|c|c|c|c|}
\hline \multicolumn{7}{|l|}{ US states: 1992-1999 } \\
\hline \multirow{3}{*}{$\begin{array}{l}\text { Dependent variable } \\
\text { Estimation method }\end{array}$} & \multicolumn{6}{|c|}{ Normalized state general obligation bond ratings (GOB rating) } \\
\hline & \multicolumn{4}{|c|}{ Random effects tobit } & \multicolumn{2}{|c|}{ Linear fixed effects } \\
\hline & (1) & $(2)$ & $(3)$ & $(4)$ & (5) & $(6)$ \\
\hline Auditor expertise & $\begin{array}{l}0.040^{* * * *} \\
(0.014)\end{array}$ & $\begin{array}{l}0.040^{* * * *} \\
(0.014)\end{array}$ & $\begin{array}{l}0.045^{* * *} \\
(0.014)\end{array}$ & $\begin{array}{l}0.040^{* * *} \\
(0.014)\end{array}$ & $\begin{array}{l}0.059^{* * *} \\
(0.005)\end{array}$ & $\begin{array}{l}0.065^{* * *} \\
(0.006)\end{array}$ \\
\hline Auditor election & - & $\begin{array}{l}0.015 \\
(0.024)\end{array}$ & $\begin{array}{l}0.028 \\
(0.024)\end{array}$ & $\begin{array}{l}0.025 \\
(0.021)\end{array}$ & - & - \\
\hline Performance audit & - & $\begin{array}{l}0.001 \\
(0.002)\end{array}$ & $\begin{array}{l}0.004^{*} \\
(0.002)\end{array}$ & $\begin{array}{l}0.004^{*} \\
(0.002)\end{array}$ & $\begin{array}{l}0.002 \\
(0.003)\end{array}$ & $\begin{array}{l}0.005 \\
(0.003)\end{array}$ \\
\hline Auditor removal & - & $\begin{array}{l}-0.006 \\
(0.012)\end{array}$ & $\begin{array}{c}-0.014 \\
(0.012)\end{array}$ & $\begin{array}{c}-0.016 \\
(0.011)\end{array}$ & - & - \\
\hline State population & $\begin{array}{r}-3.22 \mathrm{e}-09^{* *} \\
(1.50 \mathrm{e}-09)\end{array}$ & $\begin{array}{r}-3.14 \mathrm{e}-09^{* *} \\
\quad(1.53 \mathrm{e}-09)\end{array}$ & $\begin{array}{c}-3.13 \mathrm{e}-09^{* *} \\
(1.53 \mathrm{e}-09)\end{array}$ & $\begin{array}{c}-2.80 \mathrm{e}-09^{* * *} \\
(1.36 \mathrm{e}-09)\end{array}$ & $\begin{array}{r}-2.06 \mathrm{e}-08^{*} \\
(1.03 \mathrm{e}-08)\end{array}$ & $\begin{array}{r}-1.66 e-08 \\
\quad(1.03 e-08)\end{array}$ \\
\hline State r.p.c. income & $\begin{array}{l}3.01 \mathrm{e}-06 \\
(2.22 \mathrm{e}-06)\end{array}$ & $\begin{array}{l}3.34 \mathrm{e}-06 \\
(2.27 \mathrm{e}-06)\end{array}$ & $\begin{array}{l}1.10 \mathrm{e}-05^{* * *} \\
(3.33 \mathrm{e}-06)\end{array}$ & $\begin{array}{l}1.28 \mathrm{e}-05^{* * *} \\
(3.30 \mathrm{e}-06)\end{array}$ & $\begin{array}{l}3.28 e-06 \\
(4.93 e-06)\end{array}$ & $\begin{array}{l}1.33 \mathrm{e}-05 \\
(1.08 \mathrm{e}-05)\end{array}$ \\
\hline Unemployment & $\begin{array}{c}-0.005^{* * *} \\
(0.002)\end{array}$ & $\begin{array}{c}-0.005^{* * *} \\
(0.002)\end{array}$ & $\begin{array}{c}-0.012^{* * * *} \\
(0.002)\end{array}$ & $\begin{array}{c}-0.012^{* * *} \\
(0.002)\end{array}$ & $\begin{array}{c}-0.005 \\
(0.003)\end{array}$ & $\begin{array}{r}-0.011^{* *} \\
(0.005)\end{array}$ \\
\hline Aged & $\begin{array}{c}-0.761^{*} \\
(0.400)\end{array}$ & $\begin{array}{c}-0.733^{*} \\
(0.403)\end{array}$ & $\begin{array}{c}-0.637 \\
(0.398)\end{array}$ & $\begin{array}{c}-1.018^{* * *} \\
(0.395)\end{array}$ & $\begin{array}{c}-0.078 \\
(0.719)\end{array}$ & $\begin{array}{l}0.060 \\
(0.643)\end{array}$ \\
\hline Kids & $\begin{array}{c}-0.263 \\
(0.188)\end{array}$ & $\begin{array}{c}-0.258 \\
(0.191)\end{array}$ & $\begin{array}{c}-0.207 \\
(0.184)\end{array}$ & $\begin{array}{c}-0.237 \\
(0.184)\end{array}$ & $\begin{array}{c}-0.161 \\
(0.199)\end{array}$ & $\begin{array}{c}-0.188 \\
(0.144)\end{array}$ \\
\hline State r.p.c. debt & $\begin{array}{r}-2.87 \mathrm{e}-06 \\
(3.76 \mathrm{e}-06)\end{array}$ & $\begin{array}{r}-2.91 \mathrm{e}-06 \\
\quad(3.76 \mathrm{e}-06)\end{array}$ & $\begin{array}{c}-5.52 \mathrm{e}-06 \\
\quad(3.71 \mathrm{e}-06)\end{array}$ & $\begin{array}{r}-4.51 \mathrm{e}-06 \\
(3.65 \mathrm{e}-06)\end{array}$ & $\begin{array}{l}8.60 e-07 \\
(7.85 e-06)\end{array}$ & $\begin{array}{r}-5.95 e-07 \\
(6.98 e-06)\end{array}$ \\
\hline State r.p.c. expenditures & $\begin{array}{l}3.01 \mathrm{e}-06 \\
(1.46 \mathrm{e}-05)\end{array}$ & $\begin{array}{l}9.22 \mathrm{e}-07 \\
(1.48 \mathrm{e}-05)\end{array}$ & $\begin{array}{l}2.87 \mathrm{e}-05^{*} \\
(1.52 \mathrm{e}-05)\end{array}$ & $\begin{array}{l}2.80 \mathrm{e}-05^{*} \\
(1.51 \mathrm{e}-05)\end{array}$ & $\begin{array}{l}2.10 \mathrm{e}-05 \\
(2.78 \mathrm{e}-05)\end{array}$ & $\begin{array}{l}4.41 \mathrm{e}-05 \\
(2.69 \mathrm{e}-05)\end{array}$ \\
\hline Balanced budget law & - & - & - & $\begin{array}{l}0.055^{* * *} \\
(0.017)\end{array}$ & - & - \\
\hline Initiative & - & - & - & $\begin{array}{l}0.001 \\
(0.017) \\
\end{array}$ & - & - \\
\hline Year effects & - & - & Included & Included & - & Included \\
\hline $\begin{array}{l}\text { Observations } \\
\text { (pseudo) } R \text {-squared }\end{array}$ & $\begin{array}{l}309 \\
0.179\end{array}$ & $\begin{array}{l}309 \\
0.185\end{array}$ & $\begin{array}{l}309 \\
0.202\end{array}$ & $\begin{array}{l}309 \\
0.372\end{array}$ & $\begin{array}{l}309 \\
0.220\end{array}$ & $\begin{array}{l}309 \\
0.287\end{array}$ \\
\hline
\end{tabular}

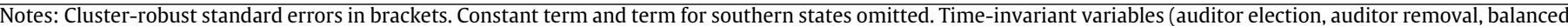
budget law, initiative) dropped in fixed effects regression.

" Denotes significance level: $0.05<p<0.1$.

** Denotes significance level: $0.01<p<0.05$.

*** Denotes significance level: $p<0.01$.

Hence, the hypothesis is that more competent auditors improve the quality and reliance of reported information, which results in improved government performance.

\section{Data on US state auditors}

I take advantage of the decentralized US federal structure. Every state has its own constitution and legal framework defining the details of its auditing institution. Variation can be observed in many different dimensions, notably in the minimum educational requirements imposed on the state auditor. Some states require the state auditor to hold at least a diploma as a Certified Public Accountant (CPA). Based on NASACT (1992) I construct a unique dataset for the period 1992-1999 containing information on a variety of institutional details of US state auditing institutions. In addition to the information on various characteristics of the US state audit offices, the dataset contains a whole range of statespecific standard control variables (Alt et al., 2006), for which summary statistics can be found in Table A.1 in the Appendix.

The standard approach for studies on the influence of fiscal institutions on government performance adopts fiscal measures such as expenditure or debt as dependent variables. In research on transparency and auditing, this strategy features several drawbacks: (1) fiscal variables might be biased due to misreporting and (2) fiscal levels might not be informative about government efficiency. First, officially reported fiscal information might be unreliable, because the quality of fiscal information itself depends on audit quality and transparency (Schelker, 2008, 2012). Hence, data quality might be endogenous to auditor characteristics. Second, high as well as low levels of expenditures and debts might be the outcomes of good as well as bad governance. E.g., especially efficient governments might face a higher demand for public goods relative to inefficient governments, which might result in higher expenditures or debts (e.g., Ferejohn, 1999).

Hence, I present evidence based on an alternative identification strategy: I adopt state General Obligation Bond (GOB) ratings that reflect a market evaluation of state fiscal performance. Similar approaches have been used by, e.g., Depken and Lafountain (2006) and Schelker (2012) to study the influence of fiscal institutions and corruption, and by, e.g., Mansi et al. (2004) in the context of corporate auditing quality. To obtain the market evaluation of anticipated audit quality I control for the influence of the reported state of public finance and I include real per capita debt and expenditures in the regression framework. In line with the general practice I focus on the 48 mainland states and exclude Alaska and Hawaii from the analysis.

The data on state credit ratings are collected from Moody's Investor Services, Fitch Ratings and Standard \& Poor's. State GOB ratings are available for a maximum of 42 US states for some or the entire period 1992-1999, but do not include states that 
Table 2

The influence of auditor expertise on state real per capita debt and expenditure.

\begin{tabular}{|c|c|c|c|c|c|c|}
\hline \multicolumn{7}{|l|}{ US states: 1992-1999 } \\
\hline Dependent variable & \multicolumn{6}{|c|}{ PANELA: log state real per capita debt } \\
\hline Estimation method & \multicolumn{4}{|c|}{ Linear random effects } & \multicolumn{2}{|c|}{ Linear fixed effects } \\
\hline & $(1)$ & $(2)$ & (3) & $(4)$ & $(5)$ & (6) \\
\hline Auditor expertise & $\begin{array}{r}-0.099^{* *} \\
(0.044) \\
\end{array}$ & $\begin{array}{c}-0.099^{* * *} \\
(0.044)\end{array}$ & $\begin{array}{r}-0.118^{* * * *} \\
(0.043)\end{array}$ & $\begin{array}{r}-0.107^{* *} \\
(0.050)\end{array}$ & $\begin{array}{r}-0.114^{* *} \\
(0.044)\end{array}$ & $\begin{array}{r}-0.139^{* * * *} \\
(0.043)\end{array}$ \\
\hline Auditor controls & - & Included & Included & Included & Included & Included \\
\hline Further controls & - & - & - & Included & - & - \\
\hline Year fixed effects & - & - & Included & Included & - & Included \\
\hline State fixed effects & - & - & - & - & Included & Included \\
\hline Observations & 384 & 384 & 384 & 384 & 384 & 384 \\
\hline R-squared & 0.261 & 0.285 & 0.202 & 0.360 & 0.152 & 0.227 \\
\hline LM (Breusch/Pagan) & 1057 & 1011 & 1020 & 1006 & - & - \\
\hline \multirow[t]{3}{*}{ Dependent variable } & \multicolumn{6}{|c|}{ PANELB: log state real per capita expenditure } \\
\hline & \multicolumn{4}{|c|}{ Linear random effects } & \multicolumn{2}{|c|}{ Linear fixed effects } \\
\hline & $(1)$ & $(2)$ & (3) & $(4)$ & $(5)$ & (6) \\
\hline Auditor expertise & $\begin{array}{r}-0.059^{* *} \\
(0.023) \\
\end{array}$ & $\begin{array}{c}-0.051^{* *} \\
(0.022)\end{array}$ & $\begin{array}{c}-0.050^{*} \\
(0.027) \\
\end{array}$ & $\begin{array}{c}-0.044 \\
(0.028) \\
\end{array}$ & $\begin{array}{c}-0.035 \\
(0.026)\end{array}$ & $\begin{array}{r}-0.035 \\
(0.033)\end{array}$ \\
\hline Auditor controls & - & Included & Included & Included & Included & Included \\
\hline Further controls & - & - & - & Included & - & - \\
\hline Year fixed effects & - & - & Included & Included & - & Included \\
\hline State fixed effects & - & - & - & - & Included & Included \\
\hline Observations & 384 & 384 & 384 & 384 & 384 & 384 \\
\hline$R$-squared & 0.144 & 0.184 & 0.310 & 0.397 & 0.558 & 0.595 \\
\hline LM (Breusch/Pagan) & 857.3 & 842.3 & 967.7 & 922.9 & - & - \\
\hline
\end{tabular}

Notes: Cluster-robust standard errors in brackets. Information on 'Auditor controls' and 'Further controls' see Table 1.

" Denotes significance level: $0.05<p<0.1$.

** Denotes significance level: $0.01<p<0.05$.

*** Denotes significance level: $p<0.01$.

have no GOB. ${ }^{2}$ The construction of the variable follows Depken and Lafountain (2006). The three principal agencies use very similar though not identical rating scales. Therefore, I construct a normalized overall rating $R_{s t}$ for each state $s$ in year $t$. The rating of state $s$ in year $t$ by agency $j=1, \ldots, n$ is $R_{s t j} \in\left\{-1, \ldots,-N_{j}\right\}$, where -1 corresponds to the highest and $-N_{j}$ to the lowest GOB rating. ${ }^{3}$ The normalized state-year rating then is $R_{s t}=\frac{1}{n} \sum_{j=1}^{n} \frac{R_{s t j}}{n_{j}}$ and it varies between -1 and 0 .

\section{Empirical strategy}

In the empirical exercise I estimate the following basic regression equation:

$y_{i t}=\alpha+\beta$ AuditorExpertise $e_{i t}+\boldsymbol{\zeta}^{\prime} \boldsymbol{A}_{i t}+\boldsymbol{\lambda}^{\prime} \boldsymbol{X}_{i t}+\varepsilon_{i t}$

where $y_{i t}$ is either the state GOB rating $\left(R_{s t}\right)$, public debt or expenditures, AuditorExpertise $e_{i t}$ is a dummy variable taking 1 if a CPA is required and 0 otherwise, $\boldsymbol{A}_{i t}$ are additional characteristics of public auditing institutions, $\boldsymbol{X}_{i t}$ is a vector of state characteristics, $\beta$ is the parameter of interest, $\zeta$ and $\lambda$ are parameter vectors and $\varepsilon$ is the error term.

When estimating the effect of auditor expertise on the normalized credit rating I estimate tobit models that take into account that $R_{s t}$ is censored at -1 and 0 . For the debt and

\footnotetext{
2 The states without GOB rating are Arizona, Colorado, Iowa, Idaho, Nebraska and South Dakota. When observing states without GOB ratings selection bias might be a concern. When approaching this potential selection problem, I do not find a significant correlation between auditor characteristics and the excluded states. Furthermore, I cannot explain any of this selection with the auditing or institutional variables in a regression framework.

3 The ratings are categorized as follows: $A A A=-1$ to $C=-21$ (lowest rating for Moody's) and $D=-22$ (S\&P and Fitch). The negative sign is chosen to make it more intuitive for the reader to interpret the regression results.
}

expenditure regressions I rely on linear models. I estimate random effects (RE) as well as fixed effects (FE) models. However, fixed effects tobit is hard to implement due to the incidental parameter problem (e.g., Greene, 2003). Therefore, I present linear fixed effects estimates, which are typically good approximations, and allow a straightforward interpretation of the effects. However, due to the high time persistence of institutional variables I prefer the random effect estimates, which reflect a long-term perspective of the effects.

Since audit offices differ in various respects, I control for the different auditor selection and removal mechanisms and for differences in the audit mandate. All regressions include a set of standard state-specific covariates. Note that all regressions on state credit ratings also include real per capita expenditures and debt in order to control for data quality and fiscal level effects.

\section{Empirical results}

Table 1 presents the regression results of auditor expertise on GOB ratings. Columns 1-4 report the random effects estimates. The results show that states demanding the state auditor to hold at least a CPA feature significantly higher credit ratings. Including year fixed effects (columns 3 and 4) and further fiscal controls (column 4) do not challenge the results. The linear fixed effects regressions in columns 5 and 6 show that the coefficients remain statistically significant, while the impact is somewhat higher in magnitude. On average, the states demanding the auditor to hold at least a CPA feature approximately a one notch higher credit rating compared to states without such a requirement. The estimated coefficients of the control variables are widely in line with previous research using the same or similar covariates (e.g., Depken and Lafountain, 2006).

Table 2, Panels $A$ and $B$ present the results on the log of real per capita debt and expenditures respectively. All random effects 
Table A.1

Summary statistics.

\begin{tabular}{|c|c|c|c|}
\hline Variable & Min.-Max. & Sample mean (std. dev.) & Description \\
\hline GOB rating & $(-0.381)-(-0.046)$ & $-0.133(-0.069)$ & $\begin{array}{l}\text { Normalized general obligation bond ratings by S\&P, Moodys and } \\
\text { Fitch (highest rating } A a a=-1, A a 1=-2, A a 2=-3 \text {, etc.) }\end{array}$ \\
\hline Government expenditures & $1298.31-2968.72$ & $1843.54(293.76)$ & Real per capita government expenditures \\
\hline Government debt & $2088.36-9376.47$ & $4539.76(1456.23)$ & Real per capita government debt \\
\hline Auditor expertise & $0 / 1$ & $0.219(0.414)$ & $\begin{array}{l}\text { Minimum education requirement: Auditor has to hold a CPA ( } 1) \text {, no } \\
\text { minimum requirement }(0)\end{array}$ \\
\hline Auditor election & $0 / 1$ & $0.354(0.479)$ & $\begin{array}{l}\text { Auditor is elected by the citizens ( } 1 \text {, auditor is appointed by the } \\
\text { legislature or the executive (0). Details see Schelker (2008) }\end{array}$ \\
\hline Performance audits & $0-3$ & $1.815(1.119)$ & $\begin{array}{l}\text { Index adding } 3 \text { types of performance audits: Economy \& efficiency, } \\
\text { program, and compliance audits. Details see Schelker (2008) }\end{array}$ \\
\hline Removal procedures & $0-3$ & $1.146(0.914)$ & $\begin{array}{l}\text { Index capturing various removal procedures for the auditor. Removal } \\
\text { by single committee or public official }(0) \text {, simple majority vote in } \\
\text { both legislative chambers required (1), supermajority required in } \\
\text { both chambers or if special procedures (2), agency head cannot be } \\
\text { removed during official term (3). Details see Schelker (2008) }\end{array}$ \\
\hline State population & $466251-3.31 e+07$ & $5491734(5794756)$ & Total state population \\
\hline State income & $10397.11-22913.70$ & $14702.42(2213.26)$ & Real per capita state income in USD \\
\hline Unemployment & $2.5-11.3$ & $5.211(1.494)$ & Unemployment rate \\
\hline Aged & $0.087-0.186$ & $0.129(0.017)$ & Fraction of the aged population $(65+)$ \\
\hline Kids & $0.071-0.264$ & $0.189(0.017)$ & Fraction of school-aged population (5-17) \\
\hline Balanced budget rule & $0 / 1$ & $0.542(0.499)$ & Balanced budget requirement (no carry-over rule) \\
\hline Voter initiative & $0 / 1$ & $0.458(0.499)$ & Voter initiative available ( 1$)$, otherwise $(0)$ \\
\hline
\end{tabular}

estimates in columns $1-4$ of both panels indicate a negative and statistically significant effect of auditor expertise on debt and expenditures. States demanding the state auditor to hold at least a CPA feature roughly $10 \%$ lower debt and $5 \%$ lower expenditures. The fixed effects regressions shown in columns 5 and 6 in both panels point to the same conclusion. The coefficients of the debt regressions in Panel $A$ confirm the random effects results, while the coefficients of the expenditure regressions in Panel $B$ are slightly lower and do not reach statistical significance. Note that these results are difficult to interpret since fiscal information might be systematically biased and pure fiscal level effects might not be very informative on government performance.

To assess the robustness of the results I follow up on two main strands of arguments. First, expertise could primarily be a matter of experience. One might worry that states requiring minimum professional education standards could also be the states that feature longer auditor tenure. Therefore, I also include variables on auditor term length and term limits, since they co-determine auditor tenure (Schelker, 2012). Second, I follow up on two main concerns of endogeneity: (1) a CPA requirement might be the result of a more general preference for higher education. Therefore, I include the share of population holding at least a high school diploma. (2) The installation of a CPA requirement might reflect fiscal preferences of citizens, which determine the institutional design and actual policy outcomes simultaneously. To proxy for state fiscal preferences I include ADA scores, which rate state legislators' ideology on a conservative-liberal scale (Anderson and Habel, 2009). All results on the influence of auditor expertise remain robust.

Overall I find that minimum professional education requirements for the state auditor are positively correlated with credit ratings and negatively with public debt and expenditures. An interpretation is that more competent auditors improve the reliability of released information.

\section{Acknowledgments}

I would like to thank Martin Besfamille, Reiner Eichenberger and an anonymous referee as well as the participants of the annual meetings of the European Public Choice Society, the International Society of New Institutional Economics, the Western Economic Association and the International Institute of Public Finance for feedback and comments.

\section{Appendix}

See Table A.1.

\section{References}

Alt, J.E., Lassen, D. Dreyer, 2006. Fiscal transparency, political parties, and debt in OECD countries. European Economic Review 50, 1403-1439.

Alt, J.E., Lassen, D. Dreyer, Rose, Shanna, 2006. The causes of fiscal transparency: evidence from the American States. IMF Staff Papers.

Anderson, S., Habel, P., 2009. Revisiting adjusted ADA scores for the US congress, 1947-2007. Political Analysis 17, 83-88.

Depken, C.A., Lafountain, C.L., 2006. Fiscal consequences of public corruption: empirical evidence from state bond ratings. Public Choice 126, 75-85.

Ferejohn, J., 1999. Accountability and authority: toward a theory of political accountability. In: Przeworski, A., Stokes, S.C., Manin, B. (Eds.), Democracy, Accountability, and Representation. Cambridge University Press, Cambridge, pp. 131-153.

Ferraz, C., Finan, F., 2008. Exposing corrupt politicians: the effect of Brazil's publicly released audits on electoral outcomes. Quarterly Journal of Economics 123 (2), 703-745.

Frey, B.S., 1994. Supreme auditing institutions: a politico-economic analysis. European Journal of Law and Economics 1, 169-176.

Greene, W., 2003. Fixed effects and bias due to the incidental parameters problem in the tobit model. Working Paper. New York University.

Mansi, S.A., Maxwell, W.F., Miller, D.P., 2004. Does auditor quality and tenure matter to investors? evidence from the bond market. Journal of Accounting Research 42 (4), 755-793.

NASACT, 1992, 1996, 2000. Auditing in the states: a summary. National Association of State Auditors. Comptrollers and Treasurers, NASACT. Lexington.

Olken, B.A., 2007. Monitoring corruption: evidence from a field experiment in Indonesia. Journal of Political Economy 115 (2), 200-249.

Schelker, M., 2008. Making Auditors Effective: Theory, Evidence, Perspectives. Nomos, Baden-Baden.

Schelker, M., 2012. The influence of auditor term length and term limits on US state general obligation bond ratings. Public Choice 150 (1), 27-49.

Schelker, M., Eichenberger, R., 2010. Auditors and fiscal policy: empirical evidence on a little big institution. Journal of Comparative Economics 38, 357-380.

von Hagen, J., Wolff, G.B., 2006. What do deficits tell us about debt? empirical evidence on creative accounting with fiscal rules in the EU. Journal of Banking and Finance 30 (12), 3259-3279. 